\title{
Business networks and localization effects for new Swedish technology-based firms' innovation performance
}

\author{
Hanna Rydehell ${ }^{1}$ (D) Anders Isaksson ${ }^{1}$ (D) Hans Löfsten ${ }^{1}$
}

Published online: 29 May 2018

(C) The Author(s) 2018

\begin{abstract}
This study examines the business networks and localization effects for new technology-based firms (NTBFs) in the context of innovation performance (the number of patents and product differentiation). In this regard, the study includes 28 variables. A survey was conducted in 2016 with 401 Swedish NTBFs that were small and young (the employment mean was 1.80 and the average age of each firm was 28.3 months). The biggest category of NTBFs was knowledge-intensive high-technology services, followed by medium high-technology manufacturing, and high-technology manufacturing. Hypotheses on how business networks and localization are related to innovation performance were tested using principal component analysis, correlation analysis, and regression analysis. The results show that the primary significant factor for innovation performance regarding business networks and localization dimensions are professional network services, while industrial and regional areas also have a positive relationship on product differentiation. Our study also shows that innovation performance enhances firms' abilities to access external financing through professional network services (e.g., venture capital companies).
\end{abstract}

Keywords Business network - Localization - Innovation performance $\cdot$ New technologybased firm $\cdot$ External financing $\cdot$ Entrepreneurship

JEL Classification $\mathrm{L} 26 \cdot \mathrm{M} 13 \cdot \mathrm{O} 30 \cdot \mathrm{O} 32$

Hanna Rydehell

hanna.rydehell@chalmers.se

Anders Isaksson

anders.isaksson@chalmers.se

Hans Löfsten

hans.lofsten@chalmers.se

1 Chalmers University of Technology, 41296 Gothenburg, Sweden 


\section{Introduction}

\subsection{Background}

New technology-based firms (NTBFs) need to collaborate with external stakeholders and build networks in order to acquire technical expertise and equipment to develop their technologies and innovation performance (e.g., Yli-Renko et al. 2001; Davidsson and Honig 2003; Löfsten 2015; Ramírez-Alesón and Fernández-Olmos 2017). A firm's portfolio of internal resources, both material and non-material, is important for its competitive advantage (Barney 1991). Besides internal resources, research has also suggested and argued that a firm's network resource endowments, which vary considerably, influence its competitive advantage (Gulati 1999; Stuart et al. 1999; Ahuja 2000).

Moreover, scholars have demonstrated that resources available at a firm's foundation create conditions which can have long-lasting effects on future performance (Boeker 1989; Bamford et al. 2000; Aspelund et al. 2005), including higher survivability if a firm possesses patents (Löfsten 2016a, b). However, during the early phase, NTBFs are resourcescarce and need to access resources to be able to develop and commercialize their technologies. Lacking resources, NTBFs position themselves nearer to business partners that can provide access to resources, such as technical expertise, information, and business advice (Uzzi 1996, 1997; Gulati 1998; Hitt et al. 2000; Löfsten and Lindelöf 2003). Thus, business networks can offer firms access to necessary assets and equipment for technology and the development of patents. Other scholars argue that business localization, as a facilitator of network creation, provides easier access to ideas and technology transfer (Deeds et al. 2000). Santoro and Gopalakrishnan (2001) showed that trust, geographic proximity, and flexible university policies for intellectual property rights, patents, and licenses are strongly associated with greater technology transfer activities.

Considering NTBFs that base their competitive advantage on technological innovation (Bollinger et al. 1983; Autio and Yli-Renko 1998; Saemundsson and Candi 2014), the development of innovation capacity through internal research and development (R\&D) or through collaborations with external partners could enhance young firms' success in launching new products in the market (Ramírez-Alesón and Fernández-Olmos 2017). Hence, for NTBFs, product differentiation is important to distinguish their products from others in the market. Considering these firms' innovation performance in the early start-up phase, it is essential to establish business networks and locate the firm favorably in relation to partners to gain access to resources needed for technological development and technology transfer.

\subsection{Innovation performance with respect to NTBFs}

One measure of innovation output is the level of patenting activity in firms. Intellectual property rights, patents, and launches of new products and services are a major consideration, such as in university-industry collaborative NTBFs. Innovative resources are required to produce technological innovation; however, they are barely sufficient to assure commercial benefits, namely new markets, from technological innovations (Löfsten 2015). There is a comprehensive literature regarding patenting for innovating technology-based firms, including surveys (Levin et al. 1987; Cohen et al. 2000), and also about strategic dimensions (Rivette and Kline 2000; Grindley and Teece 1997). 
Regarding the competitive advantage of NTBFs, though patents are important, they are also a challenge for new firms. Patents are often used as an indicator of technological development (Hottenrott et al. 2016), although the propensity to register patents varies between sectors, firms, and countries (Taylor and Silberston 1973; Fontana et al. 2013). The development of patents can be used as a measure of firm output; however, for a large number of small firms undertaking $\mathrm{R} \& \mathrm{D}$, the goal is the launch of new products and services (Löfsten and Lindelöf 2002). Haeussler et al. (2014) highlighted that the patenting process is an important support mechanism for investors in terms of updating their expectations regarding firms' quality in the very early stages of development. Conti et al. (2013) found that patents can be an important signal for start-up financing. Moreover, consistent with the research of Hottenrott et al. (2016) and Conti et al. (2013) found that patents can reduce financing constraints for small firms, particularly when information asymmetries are high and collateral values are low. In this regard, several studies, including the ones which have used empirical surveys, have investigated innovative high-technology firms and the use of patents (for instance see Löfsten 2015).

However, patents are costly and patent applications are time consuming processes, two resource parameters that NTBFs cannot afford in their early phase. The transformation in industries regarding digitalization has changed how firms, including new ventures, incorporating digital products and information and communication technology (ICT) services are focusing on open processes of knowledge sharing (Giones and Brem 2017; Nambisan 2017). Such knowledge sharing has been demonstrated to increase innovation performance of firms (Soto-Acosta et al. 2017). Thus, innovation performance is considered in the context of product or service differentiation to the market (e.g., Ramírez-Alesón and Fernández-Olmos 2017; Soto-Acosta et al. 2017). Nevertheless, patents are also indicators of product differentiation and NTBFs that need to strengthen their innovation performance and resources for this will need to collaborate with others. Collaboration with research organizations, science parks, and incubators for instance can enhance firms' ability for innovation performance, including both patents and product differentiation (e.g., RamírezAlesón and Fernández-Olmos 2017; Yu and Lee 2017). Science parks and incubator networks further enhance access to resources, such as external financing, that is important for patent development (Löfsten and Lindelöf 2003; Ferguson and Olofsson 2004; Aaboen 2009). Thus, localization close to such networks has been important for NTBFs (Löfsten and Lindelöf 2002; Vásquez-Urriago et al. 2016; Ramírez-Alesón and Fernández-Olmos 2017).

Although scholars have demonstrated the impact of business networks and business localization on new firms' performance and shown that initial resources predict future performance, most research has been conducted on the later phases of NTBFs. This leaves a gap in the early stage of the founding of firms about the effects which business networks and business localization have on innovation performance. Accordingly, this study aims to examine the effects of business networks and business localization on innovation performance measures, such as patents and product differentiation. The study contributes to the literature on NTBFs by adding business networks and localization as important factors for NTBFs' innovation performance and clarifies what resource networks and localization provide for NTBFs. Further, we broaden the view of prior research on NTBFs and the resource acquisition of such firms for patenting, arguing that a need exists to examine the effects of business networks and firms' localization in the early stage of the firms. By doing so, we can provide a clearer perspective of firms' future prospects.

The remainder of this paper is organized as follows: Sect. 2 provides a literature review and presents our hypotheses. Section 3 describes the sample and data collection processes 
together with the constructs and measures used in our investigation. Section 4 describes the statistical procedures and discusses our findings and their implications. Finally, Sect. 5 presents the study's conclusions.

\section{Theoretical framework and hypotheses}

\subsection{Innovation performance}

For technology-based firms innovation capacity and performance are essential (e.g., Bollinger et al. 1983), and thus patents and differentiation of their product or service become important to sustain competitive advantage (e.g., Ramírez-Alesón and Fernández-Olmos 2017). According to Davis and Kjaer (2003), studies have shown that common reasons to take out patents include preventing imitation, blocking competitors, earning licensing royalties, signaling territorial intent, and attracting external capital.

Patents are often used to outline aspects of innovation performance and the technological progress of countries, regions, certain specific domains and technology fields, and technology-based firms. The use of patent statistics to control developments in the field of science has expanded; moreover, the roles of different types of innovation-such as patents, copyrights, licenses, and product development—are particularly interesting (Löfsten 2015). Audretsch (2002) found that while large firms often take out more patents than small firms, the patenting rate of NTBFs (measured on a per-employee basis) is generally higher. However, other studies have used the patent holdings of small firms as indicators of the strength of their technology portfolios (Kelley and Mark 2002) and innovative efforts (Lefebvre and Lefebvre 1993). As small high-technology firms view patents and new products as opportunities to increase revenues and achieve competitive advantage, competition over these rights is often contentious (Phillips 1991).

NTBFs possess bundles of resources, particularly human resources, in the early stage. These can serve as foundations for development (e.g., Colombo and Grilli 2005). However, in general, NTBFs are resource-scarce and their initial bundles of resources are not sufficient for the firms to create competitive advantages or even to progress from ideas to the commercialization of their technologies. In addition, these firms often lack financial resources and legitimacy (Kollmer and Dowling 2004; Brinckmann et al. 2011). Consequently, in order to be able to develop and commercialize their technologies, including patent activities so that they can compete with other firms, NTBFs need to access resources external to the firms (Maine et al. 2010; Börjesson and Löfsten 2012; Löfsten 2015). Such external resources are $R \& D$ equipment and production facilities (tangible resources), and technological know-how and expertise (intangible resources) (e.g., Klofsten et al. 1998). Through business networks and close localization with universities and industryintense regions, extant research has shown that tangible resources, such as R\&D equipment and facilities, which enhance new firms' ability to operate, also become more easily accessed (Löfsten and Lindelöf 2002, 2003; Maine et al. 2010). Accordingly, networks can be regarded as vehicles for firms' resource endowments (Arya and Lin 2007), which are important for NTBFs to conduct business. In particular, in the early stage of firms, business networks and firm localization may provide NTBFs with resources which enhance the ability to develop and produce their technologies, and thus their innovation performance. We propose that NTBFs do not solely gain resources for increased competitiveness by building networks: the business networks in which they embed themselves and how they locate 


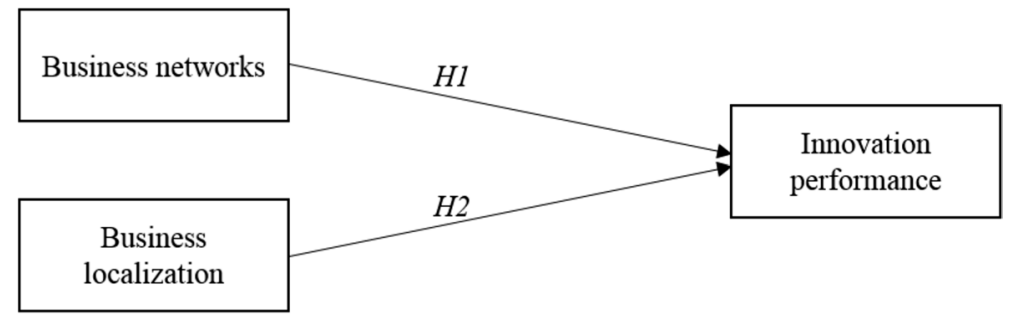

Fig. 1 Conceptual framework

themselves to the networks have direct effects on their innovation performance, such as taking out patents and differentiating their products in the market, in the early stage. Consequently, business networks and localization help NTBFs to build competitive advantages from the start. Thus, we propose the following conceptual model to illustrate the relationship between business networks and business localization, and the innovation performance (i.e., patent and product differentiation) of NTBFs (see Fig. 1).

\subsection{Business networks}

NTBFs' business networks and localization are important for resource acquisition at the firms' early phase. A business network is important for NTBFs as it enhances entrepreneurs' ability to recognize opportunities and their understanding of such opportunities (Ardichvili et al. 2003), gain legitimacy in the market (Aldrich and Fiol 1994; Elfring and Hulsink 2003, 2007; Hoang and Antoncic 2003), and gain access to scarce and vital resources and information (Uzzi 1996, 1997; Yli-Renko et al. 2001). A business network provides firms with multiple resources of which information and advice are two of the most beneficial (Löfsten and Lindelöf 2003; Löfsten 2015). Relationships in a network may also increase firms' reputations in a market (Hitt et al. 2000; Hoang and Antoncic 2003) and accelerate market valuations (Stuart et al. 1999). Moreover, it is easier to build close relationships when the reach between the actors is small; thus, localization may support NTBFs' recognition within a network, market, or industry (Uzzi 1996; Clarysse et al. 2011; Ramírez-Alesón and Fernández-Olmos 2017).

Business networks can be classified into two types of (support) networks: informal and formal (Birley 1985). The former consists of personal relationships, such as family, friends, and business partners, whereas the latter consists of suppliers of capital, banks, accountants, and lawyers (e.g., Birley 1985; Löfsten 2015). NTBFs at their start-up phase have both formal and informal ties (Elfring and Hulsink 2003), although they more commonly use informal networks to acquire resources in this stage mainly owing to the strong ties of personal relationships (Birley 1985; Uzzi 1996; Hite and Hesterly 2001). Accordingly, NTBFs benefit from informal networks which may contribute resources and information related to technological distinctiveness and innovation (for example, see Uzzi 1997; Yli-Renko et al. 2001). However, it has been demonstrated that formal networks rather than informal ones enhance firms' innovation performance through more novel resources (D'Ambrosio et al. 2017). Informal networks provide firms with tacit knowledge through trusted feedback and facilitate legitimacy through stronger connections, while formal networks provide firms with new ideas and knowledge for technological development and the discovery of opportunities. NTBFs benefit from using a mix of these networks for their innovation performance (Elfring and Hulsink 2003, 2007). Löfsten (2015) further demonstrated that formal 
networks, such as R\&D networks, lawyers, and patent advisers, are more important for NTBFs' development of patents, thus improving their acquisition of innovative resources and increasing their competitive advantages. With regard to technological distinctiveness, Börjesson and Löfsten (2012), in their study of small high-technology firms, found that business networks and R\&D networks positively relate to firms' innovation performance, such as the development of patents. NTBFs often access such business networks and R\&D networks through connections with science parks and their incubator networks (e.g., Löfsten and Lindelöf 2003). These networks can further be used by new firms as a platform to overcome liabilities of "newness" (Ferguson and Olofsson 2004; Ramírez-Alesón and Fernández-Olmos 2017).

At the early phase, NTBFs can benefit from a mix of (informal) personal relationships and formal networks for developing patents and gaining early advantages through product differentiation. In this sense, business networks provide access to important resources which facilitate firms' innovation performance (in terms of patents and product differentiation). Accordingly, we propose the following:

Hypothesis 1 Business networks are positively related to innovation performance.

\subsection{Business localization}

Beyond business networks, interactions with the stakeholders in networks also depend on firms' geographic locations (Uzzi 1996, 1997; Walker et al. 1997; Hoang and Antoncic 2003). More specifically, proximity between a firm and the network actors is important as it facilitates interactions which support learning (Deeds et al. 2000). Geographic proximity to customers and competitors is one factor of localization which supports cooperation and enhances confidence in relationships, which are both important for knowledge sharing (Ravix 2014). Thus, for NTBFs, business localization provides opportunities for collaboration which enhances knowledge transfer and technological know-how (Maine et al. 2010; Letaifa and Rabeau 2013; Presutti et al. 2013). Maine et al. (2010) further argued that technology-based firms located close to a metropolitan area benefit more from tacit knowledge transfer and have higher performance. Accordingly, business localization includes factors besides geographic proximity to customers, well-known companies, and competitors, such as closeness to regional or metropolitan areas and universities. By adopting locations which have proximity to important customers and suppliers, it is assumed that NTBFs are able to build networks which support their early development and also support the development of patents. With closer interaction with customers, new firms can further gain important information to differentiate their products in relation to competitors. Proximity to universities, certain regions, and industrial areas can also provide access to R\&D equipment, skilled technical employees, and early-stage financing that enhance new firms' innovation performance (e.g., Deeds et al. 2000; Lindelöf and Löfsten 2004; Löfsten and Lindelöf 2002, 2003; Audretsch and Lehmann 2005). Proximity to metropolitan areas, including universities, provides access to customers and competitors. These regions also provide technology-based firms with resources, access to larger customer bases, and opportunities for collaboration (Maine et al. 2010; Letaifa and Rabeau 2013; Presutti et al. 2013), which may provide firms access to resources, such as $\mathrm{R} \& \mathrm{D}$ equipment owned by larger corporations or competitors. Klevorick et al. (1995) demonstrated that firms in some industries are much "closer" to universities than others in terms of making use of academic research. Moreover, scientists cannot often manage the transition from an academic environment to 
private business (Löfsten 2015) and may need collaborative relationships with business firms. Owing to this reason, the role of science parks and incubators can enhance and foster NTBFs relationships with other firms, improving innovation performance that are derived from such collaborations with research organizations (Löfsten and Lindelöf 2002; Ferguson and Olofsson 2004; Vásquez-Urriago et al. 2016; Ramírez-Alesón and FernándezOlmos 2017).

Contrary to most studies, Letaifa and Rabeau (2013) demonstrated the positive influence of close proximity of new firms' knowledge and resource acquisition and showed that this positive effect exists only in the early stages of new firms. Further, Freel (2003) showed that proximity is more evident among small and young firms engaged in incremental rather than radical innovation. This finding is consistent with evidence from Löfsten (2015), who found no effect of proximity on the development of patents. Börjesson and Löfsten (2012) demonstrated a negative relationship between cooperation with universities and innovation performance (e.g., patents). However, for NTBFs still in the early stage, proximity may be an important element for their survival (for example, see Uzzi 1996), more specifically when acquiring technical expertise and knowledge (Presutti et al. 2013), which are important for their initial innovation performance. However, very limited research have been done on how decisions related to localization in the very early stages of firm formation affect the future performance of NTBFs. Decisions and actions in these very early years can have a long lasting (imprinting) effect on future performance (Marquis and Tilcsik 2013; Simsek et al. 2015).

Regions with industrial areas and universities further enhance a new firms' prospect to access resources needed, including financial assets. Consequently, we can assume that in the early stage, NTBFs' location can help them create new (differentiating) technologically relevant market offerings (Mason and Chakrabarti 2016). Accordingly, we propose the following hypothesis:

Hypothesis 2 Business localization is positively related to innovation performance.

\section{Sample and method}

\subsection{Sample}

This study focuses on Swedish NTBFs founded in 2013, 2014, and 2015. Sweden is known for its advanced company registration system, making it a good context in which to collect a sample of NTBFs. We used the Retriever Business database (http://business.retriever.se/) held by the Chalmers University Library (lib.chalmers.se) to identify our sample and collect secondary business data on firm size and business performance. Retriever Business is a database which contains information about all Swedish companies, regardless of their size and legal form. We sampled only firms organized as limited companies; in other words, we excluded sole proprietorship and other legal forms in order to focus on independent entities where the border between the firm and an individual is clear and also to avoid having a sample with too many hobby and lifestyle firms (which are often more common within the sole proprietorship legal form). In addition, detailed annual report data are only available for firms organized as limited companies.

In order to control for heterogeneity among new firms (Wennberg 2005; Davidsson 2007), we restricted our analysis to firms which started as independent firms (namely, 
those not belonging to a business group). Thus, we avoided including spin-offs from existing businesses and other start-ups which are not true de novo firms. Hence, from the Retriever Business database, we excluded all firms with consolidated (group) financial statement items. In order to ensure that the firms in our sample were real firms which have started some type of operation, we filtered the sample to include only those registered in certain years $(2013,2014$, and 2015), those which were active (e.g., not deregistered or liquidated), and those which were responsible for value added tax and tax prepayment. Thus, we avoided dormant companies, shelf companies, and other inactive entities. A final practical restriction in our sampling was that the firms had to have valid contact information (telephone numbers) so that we could contact them. Adopting this approach also ensures that we obtained responses from active firms (a firm with no contact information is more likely to be a non-active firm).

Studies in the new technology context have sought to define high technology (Markusen et al. 1986). According to Monck et al. (1988), there are two groups of indicators: (1) measures of resource inputs to high-technology activity, such as R\&D effort and R\&D expenditure; and (2) the employment of qualified personnel and measures of output or performance, such as growth rates, patent records, copyrights and licenses, and technological innovations. We used the Eurostat categorization of manufacturing and service industries in accordance with technological intensity. ${ }^{1}$ Butchart (1987) pioneered the industry approach in the United Kingdom (UK), which was widely applied thereafter (e.g., Brown and Mason 2014). Based on General Nomenclature of Economic Activities in the European Communities (NACE) Revision (Rev.) 2 codes, we concentrated on firms in hightechnology, medium high-technology, and knowledge-intensive high-technology services. We aggregated the firms at the two-digit level to minimize the risk of identifying individual firms in the reported data.

Our sampling resulted in a population of 2459 firms. During the telephone survey, we found 130 firms which could be deleted from the population owing to their inactivity (e.g., they never started or liquidation). Hence, the final population was 2329 firms, of which 1230 firms (52.8\%) were founded in 2013, 812 firms (34.9\%) were founded in 2014, and 287 firms $(12.3 \%)$ were founded in 2015. One reason for the skewed distribution toward firms which started in 2013 is probably that many of the youngest firms had not yet begun (they were not active and contactable in accordance with our definition). The biggest category was knowledge-intensive high-technology services with 2096 firms (90.0\%), followed by 167 firms (7.2\%) in medium high-technology manufacturing, and 66 firms $(2.8 \%)$ in high-technology manufacturing. In order to further ensure the validity of the sample, we collected all the data for the questionnaire by telephone using an external service (TNSSifo: the National Institute for Consumer Research). We received valid responses from 401 firms, a response rate of $17.2 \%$ (see Table 1), which compares positively with mail surveys of small- and medium-sized firms (for example see Chandler and Hanks (1994): 19\%; McDougall et al. (1994): 11\%; Yli-Renko et al. (2001): 24\%).

Table 1 summarizes the respondent firms' characteristics and compares these with non-responding firms. Non-responding firms have rather lower sales, profits, and profitability, but also rather higher total assets. The only significant difference between responding and non-responding firms is the founding year (which is significant at the 0.05 level). Apart from this, the table reveals no large differences between the firms. The responding

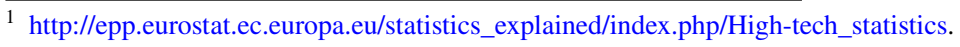


Table 1 Descriptive statistics for the surveyed new technology-based firms, 2016

1. Sample and response rate

Firms

$N$ (population): 2459

No valid firms ${ }^{\mathrm{a}}: 130$

$n$ (response): 401

Response rate (\%): 17.2

No response: 1928

2. Business data-means and standard deviations

\begin{tabular}{|c|c|c|c|c|c|c|c|}
\hline & \multicolumn{7}{|c|}{ Sample } \\
\hline & \multicolumn{3}{|c|}{$\begin{array}{l}\text { Response } \\
401 \text { firms }\end{array}$} & \multicolumn{4}{|c|}{$\begin{array}{l}\text { No response } \\
1928 \text { firms }\end{array}$} \\
\hline & $\mathrm{N}$ & Mean & SD & $\mathrm{N}$ & Mean & SD & Sig (2-tailed) \\
\hline Start year ${ }^{\mathrm{a}}$ & 401 & 2013.52 & 0.70 & 1928 & 2013.61 & 0.70 & $0.013^{*}$ \\
\hline Employment $^{\mathrm{b}}$ & 377 & 1.80 & 6.62 & 1812 & 1.72 & 10.53 & 0.858 \\
\hline Sales $^{\mathrm{c}}$ & 377 & 2177.26 & $10,724.77$ & 1812 & 2071.82 & $10,346.82$ & 0.636 \\
\hline Total capital $^{\mathrm{c}}$ & 377 & 1388.20 & 5324.68 & 1812 & 1896.56 & $20,688.24$ & 0.636 \\
\hline EBIT $^{c}$ & 377 & 234.72 & 779.00 & 1812 & 208.99 & 1356.28 & 0.722 \\
\hline Return on total capital $^{\mathrm{d}}$ & 377 & 16.47 & 47.32 & 1812 & 12.25 & 95.75 & 0.403 \\
\hline
\end{tabular}

3. Technology level, founding year, and firm age (responding firms)

\begin{tabular}{llllll}
\hline Technology level & \multicolumn{4}{l}{ Founding year and number of firms } & \\
\cline { 2 - 6 } & Year 2013 & Year 2014 & Year 2015 & Sum & Percent \\
\hline High-tech & 15 & 3 & 0 & 18 & 4.49 \\
Mid-tech & 21 & 11 & 2 & 34 & 8.48 \\
Knowledge intensive & 205 & 99 & 45 & 349 & 87.03 \\
Sum & 241 & 113 & 47 & 401 & 100.00 \\
\hline
\end{tabular}

Firm age (months)

\begin{tabular}{lllll}
\hline $\mathrm{N}$ & Minimum & Maximum & Mean & SD \\
\hline 401 & 6 & 39 & 28.32 & 8.59 \\
\hline
\end{tabular}

4. Innovation performance and technology level in the NTBFs

Number of patents 2013-2015

\begin{tabular}{lllr}
\hline & N & Mean & Std \\
\hline High-tech & 18 & 0.39 & 1.195 \\
Mid-tech & 34 & 0.18 & 0.521 \\
Knowledge intensive & 348 & 0.08 & 0.777 \\
\hline Product differentiation 2013-2015 (scale 1-5) & $\mathrm{N}$ & Mean \\
\hline & 18 & 3.61 & Std \\
\hline High-tech & 34 & 3.79 & 1.195 \\
Mid-tech & 348 & 2.84 & 1.067 \\
Knowledge intensive & & & 1.308 \\
\hline
\end{tabular}


Table 1 (continued)

5. Sectors-frequencies (\%)

\begin{tabular}{lll}
\hline & Sample & \\
\cline { 2 - 3 } & Response & No response \\
\hline Manufacturing & 8.50 & 7.28 \\
Construction & 0.25 & 0.57 \\
Wholesale and retail trade & 1.50 & 2.27 \\
Transportation and storage & 0.25 & 0.15 \\
Accommodation and food service activities & 0.00 & 0.21 \\
Information and communication & 75.00 & 79.55 \\
Financial and insurance activities & 0.50 & 0.05 \\
Real estate activities & 0.00 & 0.05 \\
Professional, scientific, and technical activities & 13.25 & 7.75 \\
Administrative and service support activities & 0.25 & 0.41 \\
Education & 0.00 & 0.31 \\
Human, health and social work activities & 0.25 & 0.78 \\
Arts, entertainment, and recreation & 0.25 & 0.46 \\
Other service activities & 0.00 & 0.16 \\
Sum & 100.00 & 100.00 \\
\hline
\end{tabular}

${ }^{\mathrm{a}}$ Year

${ }^{\mathrm{b}}$ Number of employees

c 1000 SEK

${ }^{\mathrm{d}}$ Percent

$* p<0.05$

firms are small, as measured by employment (mean: 1.80), and have a rather high return on total capital (mean: 16.47\%). The responding firms' average age is 28.3 months. The oldest firms started in January 2013 (39 months, based on the survey conducted during March-April 2016) and the youngest firms are 6 months old (see Table 1). Table 1 also shows the innovation performance and technology level of the firms (high-technology, mid-technology, and knowledge-intensive firms). Innovation performance is divided into number of patents and product differentiation. There are some differences between the firms. High-technology firms have a much higher number of patents in comparison to mid-technology and knowledge-intensive firms, and the product differentiation rate is marginally higher in high-technology and mid-technology firms in comparison to knowledgeintensive firms. Regarding the other innovation performance measure in our study, product differentiation, mid-technology and high-technology firms have rather higher means than knowledge-intensive firms.

The three largest sectors (of the responding firms - see Table 1) are manufacturing $(8.5 \%)$; information and communication $(75.0 \%)$; and professional, scientific, and technical activities (13.25\%). These total $96.75 \%$ of the responding firms. For non-responding firms, the total is $94.58 \%$. Table 6 in the Appendix shows the breakdown into different twolevel Swedish Standard Industrial Classification (SNI) codes. SNI is based on the European Union's recommended standard NACE Rev. 2 codes (Statistics Sweden 2007). Table 7 in the Appendix shows the NACE Rev. 2 codes for the responding firms. Such a classification 
is primarily an activity classification. Production units in the form of firms and local units are classified in accordance with the activities which they conduct. One firm or a local unit can have several activities (SNI codes). The largest group in the sample is computer programming, consultancy, and related activities, accounting for $57.1 \%$ of the respondents and $59.4 \%$ of the non-respondents.

\subsection{Data collection, validity, and reliability}

In order to collect data, we developed a survey questionnaire in two steps before finalizing it. First, we discussed the entrepreneurs' perception of their businesses, including key resource dimensions, in order to measure them quantitatively. The questionnaire was also thoroughly pretested and modified after discussions with six firms; namely, the survey was tested through a pre-test with six NTBFs (which were not previously interviewed) by telephone to identify uncertainties and avoid misunderstandings in the final survey. The final survey was collected during March-April 2016 by telephone through one of Sweden's largest and most respected marketing research companies (TNS-Sifo: the National Institute for Consumer Research). Thus, we improved reliability through several levels of quality control in our data collection process by using an external professional research firm.

All measures in the questionnaire were scored on a 5-point scale and a binary Yes $=1$, No $=0$. Moreover, among the non-respondents, some firms could neither be located nor did they have any activity, while the others stated that they did not have time to answer the questionnaire or did not wish to respond to the survey without providing any specific reason. Other cases of non-response resulted from wrong telephone numbers, answering machines, managers being abroad, managers refusing to participate, firm policy, and so on. One positive effect of our method is that telephone contacts generally produce higher response rates. In addition, telephone surveys generally reduce the risk of misunderstanding in interpreting the questions as the interviewers are trained and can lead the respondent through the survey. In order to increase the validity of our measures, our questionnaire was double-checked by TNS-Sifo with regard to language and ease of understanding. We further increased inter-rater reliability by using randomly selected experienced professional callers. In order to ensure consistency and quality of responses, the interview process was monitored and taped. If there were any problems with the questionnaire (e.g., misunderstandings), these were captured in the monitoring process. $41 \%$ of the statistical loss depends on the fact that the firms did not answer the phone call.

However, questionnaires tend to be weak on validity and strong on reliability. Our case deals with very small firms where there is generally only one person in a special managerial position. Our study reduced the risk of common method bias by using different headings and sections to produce overlap among the different items. Further, there are numerous well-established self-reported measures of different constructs. In our field study, we used the same scale (a Likert scale, 1-5) for 21 variables (in total 27 variables).

In order to ensure that the sample did not show any significant differences between the firms with different founding years, an independent sample t-test was undertaken. The test compared the means between two unrelated groups for the same variable. We separated the groups (start years 2013 and 2014, 2013 and 2015, and 2014 and 2015) by creating a grouping variable called start year. A Levene's test for equality of variances and t-test for equality of means, Sig. (2-tailed), showed (1) a significant difference between two variables (2013 and 2014), accountants and facility costs; (2) a significant difference between one variable (2013 and 2015), banking institutions; and (3) 
Table 2 Variables used in the study

\section{Business networks}

Definition: NTBFs can build networks which support their general development and which are located close to important customers, suppliers, researchers, and other businesses. Business networks can be categorized into formal and informal networks (Birley 1985). Informal networks include personal relationships, family ties, and business partners. Formal networks include suppliers of capital such as venture capitalists, banks, and creditors, and professionals such as accountants, lawyers, and trade associations (Das and Teng 1997)

Comparable measures: Löfsten and Lindelöf (2003) and Löfsten (2016b)

$\begin{array}{llll}\text { Measures } & \text { Mean } & \text { SD } & \text { Scale } \\ \text { 1. Accountants } & 1.59 & 1.03 & 1-5 \\ \text { 2. Banking institutions } & 1.55 & 0.95 & 1-5 \\ \text { 3. Chamber of commerce } & 1.10 & 0.47 & 1-5 \\ \text { 4. Consultants } & 1.84 & 1.19 & 1-5 \\ \text { 5. Lawyers } & 1.43 & 0.86 & 1-5 \\ \text { 6. ALMI (regional business partner) } & 1.54 & 1.13 & 1-5 \\ \text { 7. Other managing directors (CEOs) } & 2.15 & 1.28 & 1-5 \\ \text { 8. Family } & 2.78 & 1.38 & 1-5 \\ \text { 9. Patent advisers } & 1.19 & 0.67 & 1-5 \\ \text { 10. Venture capital firms } & 1.16 & 0.65 & 1-5 \\ \text { 11. Incubator network } & 1.45 & 1.01 & 1-5\end{array}$

\section{Localization}

Definition: Locations provide firms with cooperative resources for learning. The localization variables in this study relate to the factors of proximity, transport and communication, customers, competitors, other firms, and universities. Proximity between NTBFs and universities promotes an exchange of ideas (Deeds et al. 2000). Balconi et al. (2004) argued that proximity creates a geographical realm which supports a wider university-industry structure for networking and technology transfer (Niosi 2006a, b). Localization may provide firms with cooperative resources for learning and joint-knowledge creation and may fill the structural holes in the firms' composition. These benefits can provide firms with competitive advantages

Comparable measures: Löfsten (2016a)

\section{Measures}

12. Proximity to university

13. Transport/communication

14. Proximity to customers

15. Proximity to competitors in the same field

16. Proximity to similar firms

17. Local/regional advantages

18. Attractive/expansive industrial area

19. Proximity to large, well-known firms

20. Recruitment

21. Facility costs

$\begin{array}{lll}\text { Mean } & \text { SD } & \text { Scale } \\ 1.55 & 1.13 & 1-5 \\ 2.32 & 1.42 & 1-5 \\ 2.78 & 1.54 & 1-5 \\ 1.52 & 0.97 & 1-5 \\ 1.77 & 1.11 & 1-5 \\ 1.76 & 1.19 & 1-5 \\ 2.37 & 1.45 & 1-5 \\ 2.09 & 1.39 & 1-5 \\ 2.19 & 1.41 & 1-5 \\ 2.50 & 1.47 & 1-5\end{array}$


Table 2 (continued)

\section{Innovation performance}

Patents

Definition: Intellectual property rights, patents, copyrights, licences, and new products are serious considerations for university-industry collaborative firms. It has been argued that innovation performance is difficult to measure in terms of both finding an appropriate measure and finding the right measure. Innovation performance is also difficult to measure for small, established firms where measures such as market share and the level of product change are impractical. However, in this context, patents are useful (Börjesson and Löfsten 2012). According to Krammer (2009), patents present advantages and disadvantages but are the best available measure of innovation performance and are important for firms' development

Comparable measures: Krammer (2009), Börjesson and Löfsten (2012), Löfsten (2014, 2015) and Yu and Lee (2017)

\section{Product differentiation}

Definition: NTBFs need to find ways to compete against incumbent companies and offer their customers something different, unique, and novel. Operating in fast-changing environments, NTBFs also need to adapt their technologies and businesses to fit markets' needs (Andries and Debackere 2007). Successful product differentiation creates a competitive advantage for the seller, as customers view these products as unique

Comparable measures: Morris et al. (2005), Soto-Acosta et al. (2017) and Ramírez-Alesón and Fernández-Olmos (2017)

Measures

22. Number of patents

23. Product differentiation - is the firm's main product/servicecompared to other firms-very similar/very different

\section{Control variables}

Measures

24. Firm age

25. Employment

26. Sales

27. Private capital-firm start

28. External financing

$\begin{array}{lll}\text { Mean } & \text { SD } & \text { Scale } \\ 0.10 & 0.783 & \text { Number } \\ 2.96 & 1.32 & 1-5\end{array}$

\begin{tabular}{|c|c|c|}
\hline Mean & $S D$ & Scale \\
\hline 28.32 & 8.59 & Months \\
\hline 1.80 & 6.62 & $\begin{array}{l}\text { Number of } \\
\text { employees }\end{array}$ \\
\hline 2177.26 & $10,724.77$ & $1000 \mathrm{SE}$ \\
\hline 0.93 & 0.251 & $1 / 0$ \\
\hline 0.18 & 0.382 & $1 / 0$ \\
\hline
\end{tabular}

no significant differences (2014 and 2015). There was only one significant difference between the business localization variable, proximity to university (2013 and 2014). There were also no significant differences between the resource variables over the years 2013-2015. As the differences between the years of these variables were very small, the differences were not considered serious.

\subsection{Measures and statistical analysis}

The empirical base consists of 27 variables (see Table 2). Business networks consist of 11 variables (measured on 5-point Likert scales), localization consists of 10 variables (measured on 5-point Likert scales), and the dimension innovation performance has two variables (number of patents and product differentiation). The analysis also includes five control variables for firm age and size based on secondary data sources (annual reports) measured in months, employment, and sales. In addition, there is a financing dimension; namely, if a firm has external financing and if the founder has provided private capital. Financial 
capital as a resource has been highlighted as interesting in relation to networks. Further, innovation performance can be an important tool to signal quality to external investors who are venture capitalists (Haeussler et al. 2014). Including control variables helps to separate the statistical results from firm age, size, and level of financing. Table 2 shows that $93 \%$ of the surveyed firms used private capital when they began; however, only $18 \%$ of the firms attracted external financing from when they started.

Our statistical analysis had three steps. First, we applied a principal component analysis (PCA) to convert the set of observations of potentially correlated variables into a set of linearly uncorrelated variables called "principal components" (factors). PCA is a variable reduction technique and reduces the number of observed variables to a smaller number of principal components which account for most of the variance of the observed variance. PCA is used when variables are correlated and is a large sample procedure. Table 8 in the Appendix shows the correlations between the 21 variables in our study and they are highly correlated.

Moreover, exploratory procedures are more accurate when multiple variables represent each factor in the analysis, ideally between three and five measured variables per factor (MacCallum 1990; Safón 2009). The Kaiser-Meyer-Olkin (KMO) measure was calculated to determine sampling adequacy. This measure ranges between 0 and 1 . Values closer to 1 are preferred, with a suggested minimum value of 0.600 . Second, a correlation analysis identified the statistically significant measures (principal components and variables). Third, we used a regression analysis to test the link between the dependent variables (number of patents and product differentiation) and independent principal components.

\section{Analysis}

\subsection{Principal component and correlation analysis}

The PCA reveals four significant principal components (see Tables 9 and 10 in the Appendix) related to business networks and localization. The two principal components for business networks are professional network services $(\alpha=0.658)$ and management networks $(\alpha=0.513)$. The two principal components for localization are proximity $(\alpha=0.791)$ and region and industrial area $(\alpha=0.560)$. We discarded one principal component for business networks from further analysis $(\alpha=0.386)$ as it lacked reliability. However, some of Cronbach's alpha values are also fairly low. Opinions differ about the ideal Cronbach's alpha value; some experts have recommended a value of at least 0.900 for instruments used in clinical settings (Nunnally and Bernstein 1994), while others have suggested that an alpha of 0.700 is acceptable for a new instrument (DeVellis 1991; DeVon et al. 2007). According to Hair et al. (1995), the generally agreed-upon lower limit for Cronbach's alpha is 0.700 , although this may decrease to 0.600 in exploratory research. George and Mallery (2003, 231) provided the following parameters: " $\alpha>0.900$ E Excellent, $\alpha>0.800$ —Good, $\alpha>0.700$-Acceptable, $\quad \alpha>0.600$-Questionable, $\alpha>0.500$-Poor, and $\alpha<0.500$ Unacceptable." Thus, one principal component with a Cronbach's alpha below 0.500 was removed from our analysis. All KMO values were above 0.600 and all test statistics for Bartlett's test of sphericity were 0.000 .

Considering the results as a whole, we decided to use four principal components in the analysis. We then performed a Pearson correlation analysis to predict the statistically significant principal components and variables (significant at least at the 0.05 level—see 


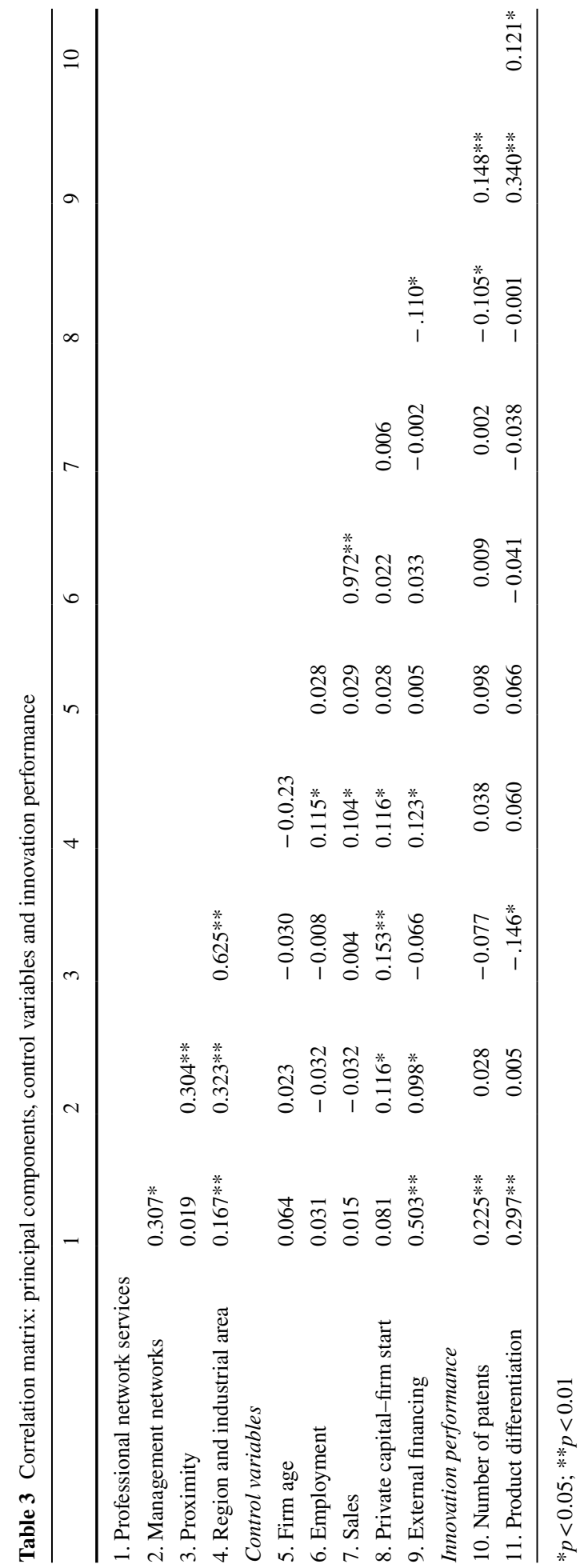


Table 4 Regression analysis ${ }^{\mathrm{a}}$ (Hypotheses 1 and 2) dependent variable: innovation performance-number of patents

\begin{tabular}{lll}
\hline & Model $1^{\mathrm{b}}$ & Model $2^{\mathrm{c}}$ \\
\hline Professional networks services & $0.061^{* * *}$ & $0.062^{* * *}$ \\
Management networks & $(0.014)$ & $(0.016)$ \\
& -0.009 & -0.008 \\
Proximity & $(0.016)$ & $(0.016)$ \\
& $-0.021^{*}$ & -0.019 \\
Region and industrial area & $(0.011)$ & $(0.11)$ \\
Intercept & 0.017 & 0.018 \\
& $(0.012)$ & $(0.12)$ \\
Private capital-firm start & -0.221 & 0.095 \\
& $(0.145)$ & $(0.192)$ \\
External financing & & $-0.395^{*}$ \\
N & & $(0.163)$ \\
Adjusted R & & 0.016 \\
\hline
\end{tabular}

Unstandardized coefficients beta and standard errors (in parentheses)

a* $p<0.05 ; * * p<0.01 ; * * * p<0.005$

${ }^{\text {b Sig. } 0.000 * * * *}$

${ }^{\mathrm{c}}$ Sig $0.000 * * *$

Table 3). Correlation matrixes present simple relationships among principal components and variables (Pearson correlation, -1 to 1 ). The results show correlations between innovation performance (number of patents) and professional network services, and the two control variables regarding financing issues: private capital-firm start and external financing. There are also connections between the two control variables regarding financial issues, several of the business networks, and localization principal components. Further, the control variable sales has relationships with the principal component region and industrial area.

\subsection{Regression analysis}

Regression analysis was the third step in the statistical analysis and was based on the principal components constructed from the aggregated statistical means of the underlying measures. As all measures were expressed in Likert-type scales (from 1 to 5 or 1/0), there was no risk that extreme values affected the aggregated means. The two multivariate linear models presented below test the relationships between the dependent variable innovation performance (number of patents and product differentiation), the four independent principal components, and the two control variables regarding financing.

$$
I P=\beta_{0}+\beta_{1} P N+\beta_{2} M N+\beta_{3} P Y+\beta_{4} R A+\beta_{5} P C+\beta_{6} E F,
$$

where $\mathrm{IP}=$ Innovation performance, $\mathrm{PN}=$ Professional network services, $\mathrm{MN}=$ Management networks, $\mathrm{PY}=$ Proximity, $\mathrm{RA}=$ Region and industrial area, $\mathrm{PC}=$ Private capital-firm start, $\mathrm{EF}=$ External financing. 
Table 5 Regression analysis ${ }^{\mathrm{a}}$ (Hypotheses 1 and 2) dependent variable: Innovation performance-product differentiation

\begin{tabular}{lll}
\hline & Model $3^{\mathrm{b}}$ & Model $^{\mathrm{c}}$ \\
\hline Professional networks services & $0.131^{* * *}$ & $0.077^{* * *}$ \\
Management networks & $(0.023)$ & $(0.026)$ \\
& -0.023 & -0.018 \\
Proximity & $(0.026)$ & $(0.025)$ \\
& $-0.068^{* * *}$ & $-0.059 * * *$ \\
Region and industrial area & $(0.17)$ & $(0.017)$ \\
Intercept & $0.054 * *$ & $0.042 *$ \\
Private capital-firm start & $(0.019)$ & $(0.019)$ \\
& 2.322 & 2.309 \\
External financing & $(0.234)$ & $(0.305)$ \\
& & 0.268 \\
$\mathrm{~N}$ & & $(0.258)$ \\
Adjusted $\mathrm{R}^{2}$ & & $0.797 * *$ \\
\hline
\end{tabular}

Unstandardized coefficients beta and standard errors (in parentheses)

$\mathrm{a} * p<0.05 ; * * p<0.01 ; * * * p<0.005$

${ }^{\text {b Sig. } 0.000 * * * *}$

${ }^{\mathrm{c}} \operatorname{Sig} 0.000^{* * * *}$

Tables 4 and 5 report the results of the regression analyses and indicate two significant regression models. We conducted one test to verify the findings. Predictors which are highly collinear or linearly related can cause problems with regression coefficient estimates. Multicollinearity occurs in regression analysis when there is a high correlation between at least one independent variable and a combination of the other independent variables. Table 11 in the Appendix shows the collinearity statistics (tolerance and variance inflation factor (VIF)). A VIF greater than 5 is generally considered evidence of multicollinearity, and a tolerance below 0.20 is a cause for concern. However, we could not find any indication of multicollinearity in the statistical analysis.

The four regression models are significant $(p<0.005)$ and the conceptual framework can be supported. However, hypotheses 1 and 2 are only partly supported. In models 1 and 2 , the dependent variable innovation performance (number of patents) is strongly significant and positively related to professional network services. In model 1, proximity is significant and negatively related to innovation performance. In model 2, private capital-firm start is significant and negatively related to innovation performance. In contrast, proximity has a negatively significant connection at the individual principal component level in the first regression model. In models 3 and 4, professional networks' services is strongly significant and strongly related to the dependent variable innovation performance (product differentiation). We also observe significant relationships between proximity (negative), region and industrial area (positive), and product differentiation. There is also a significant relationship between external financing and product differentiation.

Considered together, the regression analyses imply that the principal component professional network services is the most important individual principal component for 
innovation performance (number of patents and product differentiation). The next section discusses the implications of these results for theory and practice.

\subsection{Discussion}

Technological innovation and differentiation from competitors are important for NTBFs' (innovation) performance in their early phases. The development of a new product or service and development of patents create incentives for these young firms to collaborate with others, such as research organizations and customers, particularly as NTBFs in their early stages are resource scarce. Business networks can help new firms acquire the resources needed and enhance a firms' innovation performance (Yli-Renko et al. 2001; Elfring and Hulsink 2003; Börjesson and Löfsten 2012). Moreover, firms' localization adds further support by enabling close relationships to access networks (Hoang and Antoncic 2003; Maine et al. 2010; Vásquez-Urriago et al. 2016). Thus, this proposes that NTBFs' business networks and their localization to such networks should have a positive effect on innovation performance at the start-up phase. However, the results indicate some contradictory effects in certain cases of NTBFs' early phase.

Our results show a (partly) positive relationship between NTBFs' business networks and innovation performance, both with regard to the number of patents and product differentiation. More specifically, the results show that one principal component, the independent variable professional network services, is positively related to NTBFs' innovation performance. Such professional networks, which consist of lawyers and patent advisers, have been demonstrated to support the development of patents for firms' technologies (Löfsten 2015). These professional network services also include incubator networks, regional support organizations, and venture capital firms which NTBFs can benefit from financially, thus indicating networks that are more formal. Incubator networks can accelerate NTBFs' development (Löfsten and Lindelöf 2003; Aaboen 2009); hence, they can enhance firms' ability to access external financing, which supports the development of patents in the firms' early stage. This is demonstrated by the positive correlation between professional network services and external financing in our results, and the positive relationship of these to innovation performance.

Moreover, the results find no support for a mix of formal and informal networks for NTBFs as being demonstrated to be important in the early stages (e.g., Elfring and Hulsink 2003, 2007). Rather, the results are consistent with research arguing that formal networks have a stronger effect for firms' innovation performance, both with regard to patents (e.g., Börjesson and Löfsten 2012; Löfsten 2015; D'Ambrosio et al. 2017) and product differentiation (e.g., Ramírez-Alesón and Fernández-Olmos 2017; Soto-Acosta et al. 2017).

Moreover, regarding the financing variables, private capital-firm start is significantly and negatively related to innovation performance (number of patents). In our sample of early NTBFs, most of the firms (93\%) had private capital at their founding in comparison to only a few (18\%) which had attracted external financing. There may be an explanation in that those NTBFs which initially focus more on private capital do not possess cutting-edge technology which needs patenting; thus, patents are not their core resources. Further, patents can be expected to attract external capital (Davis and Kjaer 2003). In this regard, our study reveals that few early firms had patents. This finding could also explain why few firms initially attracted external financing.

As our study demonstrates, in the early stage, only every tenth firms in the sample had a patent. This finding can be compared with Löfsten (2015), where $41 \%$ of the 
NTBFs had at least one patent. However, Löfsten (2015) included only NTBFs which were working with business incubators, whereas the current study includes both academic and corporate NTBFs and is not restricted to science parks or firms which are connected with business incubators. The results also reveal that patents are less common for NTBFs during the early phase; however, developing more formal networks (professional network services) from the beginning can enhance young firms' innovative abilities. Hence, it is useful to facilitate the development process for patenting by providing advisory and financial support.

Although new NTBFs have attracted external financing in the early stages, our results reveal that external financing is significantly and positively related to innovation performance (product differentiation). Hence, even if few NTBFs have patents in the early startup phase, the way they differentiate their technology (product or service) in relation to others in the market can enhance their ability to attract external financing. The increase in the number of knowledge-intensive firms [related to digitalization and ICT (e.g., Giones and Brem 2017)] in comparison to high-technology manufacturing firms (as also shown in our sample) may provide explanation for focusing on product differentiation rather than patents as an innovation performance measure. Nevertheless, more focus on digitalization in all industries also effects high-technology manufacturing firms, increasing openness and knowledge sharing for product development (for example, see Nambisan 2017; SotoAcosta et al. 2017). However, these NTBFs also need to differentiate more to be competitive. Our sample shows that regardless of the technology level, product differentiation is more common than patenting among the current NTBFs. This maybe owing to the fact that the patent process is costly and time consuming, which is challenging for young companies to handle. Moreover, with a change in the market related to digitalization, NTBFs may easily attract external financing from investors such as venture capitalists if their product can be demonstrated as different from what is already there in the market, showing possibilities for sales growth (for example, see Giones and Brem 2017).

With regard to the business localization of NTBFs in the early phase, our results show contradictory results. Proximity, as one component of business localization, is significantly related to innovation performance, both in terms of patents and product differentiation. However, contrary to expectations, the relationship is negative. Although proximity enhances collaboration and promotes knowledge transfer, this situation appears to be more evidently related to universities which provide new firms with advantages, as demonstrated by prior research (e.g., Deeds et al. 2000; Maine et al. 2010). In contrast, this study reveals that proximity to customers, competitors, similar firms, large and well-known firms, and expansive industrial areas does not support NTBFs' innovation performance in the early start-up phase. Instead, the current research adds to prior studies on NTBFs which have demonstrated that proximity has less of an impact on (radical) innovation in firms' later stages (Freel 2003), now also including early stages of new firms. Löfsten (2015) did not even find a relationship between proximity and the development of patents. Accordingly, proximity may provide certain advantages for NTBFs in the early stages; however, it does not provide advantages regarding NTBFs' innovation performance. This can also be explained by the correlation between proximity and more informal networks (management networks) that have been demonstrated by previous research to enhance firms' reputation in the market and access to information and resources (e.g., Uzzi 1997; Elfring and Hulsink 2003; Letaifa and Rabeau 2013). However, these strong connections do not improve new firms' access to novel ideas and resources, contrary to formal networks (e.g., Freel 2003; D’Ambrosio et al. 2017). 
In contrast to the negative relation of proximity to NTBFs' innovation performance, the component region and industrial areas is significantly and positively related to innovation performance (product differentiation). In contrast to studies that found negative relationships between university cooperation and small high-technology firms' innovation performance (e.g., Börjesson and Löfsten 2012), our results indicate that early stage NTBFs benefit from business localization close to universities and regional advantages, including possibilities for recruitment and beneficial facility costs. Such areas with access to support networks, such as incubators and science parks, can support young firms in their technology development and for differentiating it in the market (e.g., Löfsten and Lindelöf 2002; Maine et al. 2010; Ramírez-Alesón and Fernández-Olmos 2017).

\subsection{Implications and future research}

We believe that this paper provides contributions for researchers and practitioners. For researchers studying NTBFs, this study adds to prior research by investigating NTBFs in the early stage of development. This is an approach which has not been appropriately considered by prior research. Studying NTBFs in the early phase broadens the view of these firms and highlights what may be important for firms' initial resource acquisition in order to enhance innovation performance. The study not only captures the early phase of NTBFs, but it does so when the firms are in their current phases, an approach which contributes to reduced memory bias. Further, we study a broad sample of NTBFs in different industry sectors; thus, we capture a general view of NTBFs and their innovation performance (number of patents and product differentiation) in comparison to prior studies. Moreover, this study adds insight to the explanation of how young firms' business networks and business localization impact a key firm performance indicator, namely innovation performance, which is important for value creation.

Accordingly, the study has theoretical implications. In this regard, it uses a perspective of the effects of networks and localization as vital resource dimensions, on young NTBFs' early innovation performance. Thus, the study provides implications for the impact of business networks and localization on NTBFs' innovation performance. More formal business networks provide initial support for operations, new product development, and particularly, patents and to differentiate young firms' products in relation to competitors. Overall, business networks are useful in the early stage for acquiring technical knowledge, such as those regarding the process of patenting and for attracting initial funding. However, depending on the type of network, business localization should be considered for reasons other than firms' innovation performance.

For practitioners, such as founders and managers, this study's results have implications about how they should consider business localization during the early phase in addition to their business networks. For instance, business location is important in the emerging stage. However, founders and managers should be aware of the negative effect which proximity may have on the ability to be innovative, regarding patent development. However, regions and industrial areas consisting of universities and science parks may provide initial support for NTBFs' innovation performance, particularly concerning information and resources for product differentiation. Further, in the early phase, NTBFs should consider the positive effect which more formal networks (professional network services) may have on the ability to attract external capital, on the development of patents, and for product differentiation. These implications are important for policymakers, and particularly incubators and science 
park managers who select and support NTBFs based on their R\&D and business dimensions and support their development through the incubator and science park.

However, this study has several limitations, which also offer promising avenues for future research. The survey data were based on a single point in time, but business networks and localization variables evolve with interaction. We hope that future research continues uncovering the effects of NTBFs' business networks and business localization, particularly concerning the divided effects which studies have demonstrated regarding proximity. Future research should study NTBFs over time to uncover when business localization may be positive for firms in terms of resource acquisition and knowledge transfer between stakeholders. More research is required to explain the effects of business networks and localization on NTBFs' initial business performance for young technological ventures.

\section{Conclusions}

Business networks and localization provide NTBFs with resources which are important for value creation that can be captured in the early phase. However, the effects of these resource dimensions differ and may not be positive. Our empirical results lead to several conclusions. Professional network services, as a business network dimension, are the most important factor for NTBFs' innovation performance; namely, the number of patents and product differentiation, which are key to the start of operations. However, proximity, as a business localization dimension, negatively affects young firms' innovation performance; hence, it should be carefully considered for the purpose of differentiation and patent development in the early stage of firms in order to avoid negative consequences. In particular, new firms should not view proximity as an important factor for innovative ability; instead, they should use such a resource dimension of their business for other reasons. On the other hand, early stage NTBFs would benefit from considering other business localization factors for their innovation performance. This study concludes that, in general, NTBFs need to consider their external links, not solely in later phases of development, but also in the early phase in order to access resources for initial innovation performance.

Acknowledgements We gratefully acknowledge the financial support from the Peter Wallenberg Foundation for Economics and Technology.

Open Access This article is distributed under the terms of the Creative Commons Attribution 4.0 International License (http://creativecommons.org/licenses/by/4.0/), which permits unrestricted use, distribution, and reproduction in any medium, provided you give appropriate credit to the original author(s) and the source, provide a link to the Creative Commons license, and indicate if changes were made.

\section{Appendix}

See Tables 6, 7, 8, 9, 10 and 11. 
Table 6 Sectors by two-level SNI code

Sectors-frequencies-industry codes (two level) (\%)

\begin{tabular}{|c|c|c|}
\hline & \multicolumn{2}{|l|}{ Sample } \\
\hline & Response & No response \\
\hline Manufacturing & 8.50 & 7.28 \\
\hline Manufacture of food products & 0.00 & 0.05 \\
\hline Manufacture of beverages & 0.00 & 0.10 \\
\hline Manufacture of chemicals and chemical products & 0.75 & 0.46 \\
\hline Manufacture of basic pharmaceutical products & 0.00 & 0.05 \\
\hline Manufacture of fabricated metal products & 0.25 & 0.36 \\
\hline Manufacture of computers, electronics, and optical products & 1.75 & 1.65 \\
\hline Manufacture of electrical equipment & 0.75 & 0.78 \\
\hline Manufacture of machinery and equipment & 3.25 & 1.91 \\
\hline Manufacture of motor vehicles & 0.75 & 0.78 \\
\hline Manufacture of other transport equipment & 0.25 & 0.21 \\
\hline Other manufacturing & 0.50 & 0.93 \\
\hline Repair and installation of machinery and equipment & 0.25 & 0.00 \\
\hline Information and communication & 75.00 & 79.55 \\
\hline Publishing activities & 0.74 & 0.57 \\
\hline Motion picture, video, and television program production & 10.20 & 11.88 \\
\hline Programming and broadcasting activities & 0.00 & 0.10 \\
\hline Telecommunications & 1.49 & 1.55 \\
\hline Computer programming, consultancy, and related activities & 57.10 & 59.40 \\
\hline Information service activities & 5.47 & 6.05 \\
\hline Professional, scientific, and technical activities & 13.25 & 7.75 \\
\hline Legal and accounting activities & 0.25 & 0.10 \\
\hline Activities of head offices: management consultancy activities & 1.75 & 1.45 \\
\hline Architectural and engineering activities & 3.25 & 0.88 \\
\hline Scientific research and development & 5.75 & 3.87 \\
\hline Advertising and market research & 0.75 & 0.57 \\
\hline Other professional, scientific and technical activities & 1.50 & 0.88 \\
\hline
\end{tabular}


Table 7 Distribution of responding firms on industry (NACE 2)

\begin{tabular}{|c|c|c|}
\hline NACE 2 & Number of firms & Cumulative $\%$ \\
\hline 20 & 3 & 0.7 \\
\hline 25 & 1 & 1.0 \\
\hline 26 & 7 & 2.7 \\
\hline 27 & 3 & 3.5 \\
\hline 28 & 13 & 6.7 \\
\hline 29 & 3 & 7.5 \\
\hline 30 & 1 & 7.7 \\
\hline 32 & 2 & 8.2 \\
\hline 33 & 1 & 8.5 \\
\hline 43 & 1 & 8.7 \\
\hline 45 & 2 & 9.2 \\
\hline 46 & 2 & 9.7 \\
\hline 47 & 2 & 10.2 \\
\hline 49 & 1 & 10.5 \\
\hline 58 & 3 & 11.2 \\
\hline 59 & 41 & 21.4 \\
\hline 61 & 6 & 22.9 \\
\hline 62 & 229 & 80.0 \\
\hline 63 & 22 & 85.5 \\
\hline 64 & 1 & 85.8 \\
\hline 66 & 1 & 86.0 \\
\hline 69 & 1 & 86.3 \\
\hline 70 & 7 & 88.0 \\
\hline 71 & 13 & 91.3 \\
\hline 72 & 23 & 97.0 \\
\hline 73 & 3 & 97.8 \\
\hline 74 & 6 & 99.3 \\
\hline 77 & 1 & 99.5 \\
\hline 86 & 1 & 99.8 \\
\hline 90 & 1 & 100.0 \\
\hline Total & 401 & \\
\hline
\end{tabular}




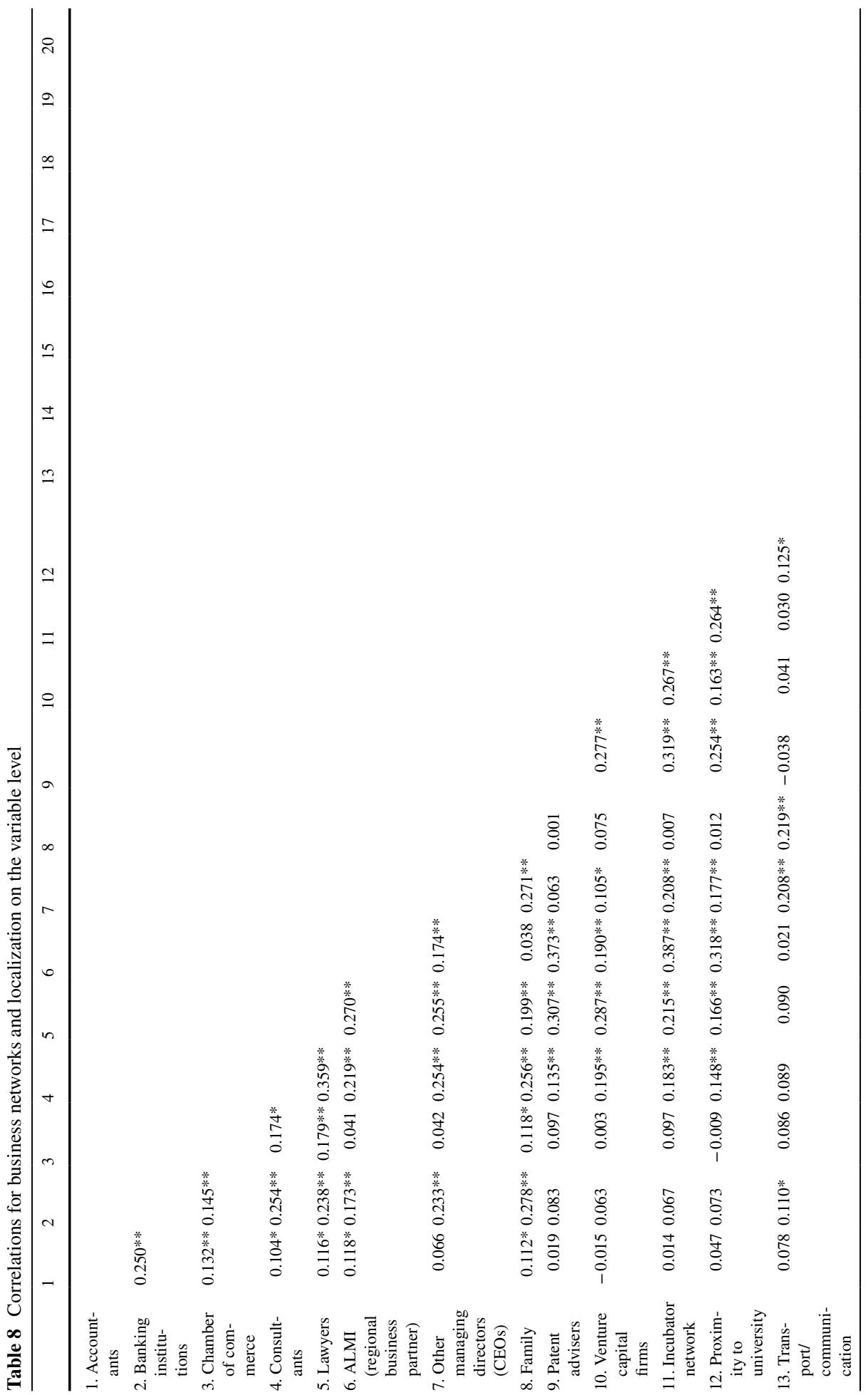




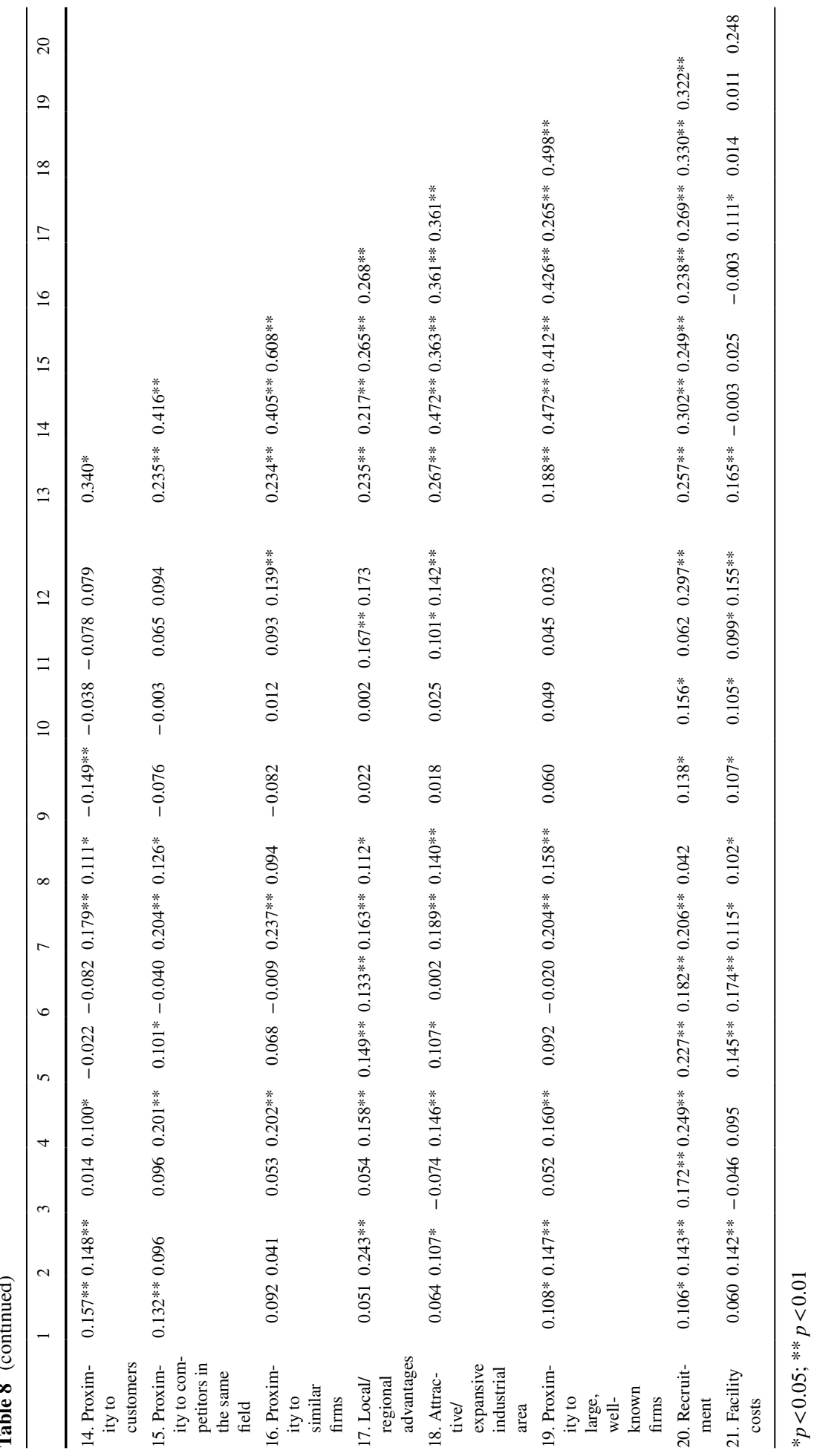


Table 9 Varimax rotation (rotated component matrix), ${ }^{\text {abc }}$ business networks

\begin{tabular}{lccc}
\hline $\begin{array}{l}\text { Variables Component } \\
\text { names } \\
\text { Cronbach } \alpha\end{array}$ & $\begin{array}{l}\text { Component 1 Professional } \\
\text { network services } \\
\alpha=0.658\end{array}$ & $\begin{array}{l}\text { Component 2 Management } \\
\text { networks } \\
\alpha=0.513\end{array}$ & $\begin{array}{c}\text { Component 3 } \\
\end{array}$ \\
\hline Variable $^{\mathrm{e}}$ & & $\alpha=0.386$ \\
1 & -0.16 & 0.057 & \\
2 & 0.048 & 0.474 & $0.500^{\mathrm{d}}$ \\
\hline 3 & 0.105 & 0.043 & 0.494 \\
4 & 0.280 & 0.579 & 0.606 \\
5 & 0.490 & 0.415 & 0.166 \\
6 & 0.682 & 0.063 & 0.197 \\
7 & 0.142 & 0.679 & 0.190 \\
8 & -0.127 & 0.729 & -.0 .087 \\
9 & 0.735 & -0.072 & 0.116 \\
10 & 0.555 & 0.236 & 0.104 \\
11 & 0.694 & 0.079 & -0.231 \\
\hline
\end{tabular}

${ }^{\mathrm{a} C u m u l a t i v e ~ v a r i a n c e} 48.298 \%$

${ }^{\mathrm{b}}($ Cronbach $\alpha)>0.500$

${ }^{\mathrm{c}} \mathrm{KMO}=0.765$ and Bartlett's test of sphericity $=0.000$

${ }^{\mathrm{d} C r o n b a c h} \alpha<0.500$. Excluded from further analysis

${ }^{\mathrm{e}}$ See Table 6

Table 10 Varimax rotation (rotated component matrix), ${ }^{\text {abc }}$ localization

\begin{tabular}{lll}
\hline $\begin{array}{l}\text { Variables Component } \\
\text { names } \\
\text { Cronbach } \alpha\end{array}$ & $\begin{array}{l}\text { Component 1 Prox- } \\
\text { imity } \\
\alpha=0.791\end{array}$ & $\begin{array}{l}\text { Component 2 Region } \\
\text { and industrial area } \\
\alpha=0.560\end{array}$ \\
\hline Variable $^{\mathrm{d}}$ & & \\
12 & 0.026 & 0.636 \\
13 & 0.355 & 0.434 \\
14 & 0.737 & 0.088 \\
15 & 0.743 & 0.055 \\
16 & 0.752 & 0.066 \\
17 & 0.396 & 0.404 \\
18 & 0.687 & 0.205 \\
19 & 0.739 & 0.054 \\
20 & 0.346 & 0.637 \\
21 & -0.161 & 0.706 \\
\hline
\end{tabular}

${ }^{\mathrm{a}}$ Cumulative variance $48.296 \%$

${ }^{\mathrm{b}}($ Cronbach $\alpha)>0.500$

${ }^{\mathrm{c}} \mathrm{KMO}=0.816$ and Bartlett's test of sphericity $=0.000$

${ }^{\mathrm{d}}$ See Table 6 
Table 11 Collinearity statistics

\begin{tabular}{|c|c|c|c|c|}
\hline & \multicolumn{2}{|l|}{ Model 1} & \multicolumn{2}{|l|}{ Model 2} \\
\hline & Tolerance & VIF & Tolerance & VIF \\
\hline Professional network services & 0.880 & 1.137 & 0.670 & 1.492 \\
\hline Management networks & 0.800 & 1.250 & 0.798 & 1.254 \\
\hline Proximity & 0.583 & 1.717 & 0.569 & 1.757 \\
\hline Region and industrial area & 0.574 & 1.741 & 0.562 & 1.780 \\
\hline Private capital-firm start & & & 0.945 & 1.058 \\
\hline \multirow[t]{3}{*}{ External financing } & & & 0.711 & 1.406 \\
\hline & \multicolumn{2}{|l|}{ Model 3} & \multicolumn{2}{|l|}{ Model 4} \\
\hline & Tolerance & VIF & Tolerance & VIF \\
\hline Professional network services & 0.877 & 1.140 & 0.668 & 1.497 \\
\hline Management networks & 0.802 & 1.247 & 0.799 & 1.251 \\
\hline Proximity & 0.585 & 1.708 & 0.571 & 1.750 \\
\hline Region and industrial area & 0.576 & 1.736 & 0.563 & 1.775 \\
\hline Private capital-firm start & & & 0.945 & 1.059 \\
\hline External financing & & & 0.711 & 1.407 \\
\hline
\end{tabular}

\section{References}

Aaboen, L. (2009). Explaining incubators using firm analogy. Technovation, 29(10), 657-670.

Ahuja, G. (2000). Collaboration networks, structural holes, and innovation: a longitudinal study. Administrative Science Quarterly, 45(3), 425-455.

Aldrich, H. E., \& Fiol, C. M. (1994). Fools rush in? The institutional context of industry creation. Academy of Management Review, 19(4), 645-670.

Andries, P., \& Debackere, K. (2007). Adaptation and performance in new businesses: Understanding the moderating effects of independence and industry. Small Business Economics, 29(1-2), 81-99.

Ardichvili, A., Cardozo, R., \& Ray, S. (2003). A theory of entrepreneurial opportunity identification and development. Journal of Business Venturing, 18(1), 105-123.

Arya, B., \& Lin, Z. (2007). Understanding collaboration outcomes from an extended resource-based view perspective: the roles of organizational characteristics, partner attributes, and network structures. Journal of Management, 33(5), 697-723.

Aspelund, A., Berg-Utby, T., \& Skjevdal, R. (2005). Initial resources' influence on new venture survival: a longitudinal study of new technology-based firms. Technovation, 25(11), 1337-1347.

Audretsch, D. B. (2002). The dynamic role of small firms: Evidence from the U.S. Small Business Economics, $18(1-3), 13-40$.

Audretsch, D. B., \& Lehmann, E. E. (2005). Does the knowledge spillover theory of entrepreneurship hold for regions? Research Policy, 34(8), 1191-1202.

Autio, E., \& Yli-Renko, H. (1998). New, technology-based firms in small open economies-An analysis based on the Finnish experience. Research Policy, 26(9), 973-987.

Balconi, M., Breschi, S., \& Lissoni, F. (2004). Networks of inventors and the role of academia: An exploration of Italian patent data. Research Policy, 33(1), 127-145.

Bamford, C. E., Dean, T. J., \& McDougall, P. P. (2000). An examination of the impact of initial founding conditions and decisions upon the performance of new bank start-ups. Journal of Business Venturing, 15(3), 253-277.

Barney, J. (1991). Firm resources and sustained competitive advantage. Journal of Management, 17(1), 99-120.

Birley, S. (1985). The role of networks in the entrepreneurial process. Journal of Business Venturing, 1(1), 107-117.

Boeker, W. (1989). Strategic change: The effects of founding and history. Academy of Management Journal, 32(3), 489-515. 
Bollinger, L., Hope, K., \& Utterback, J. M. (1983). A review of literature and hypotheses on new technology-based firms. Research Policy, 12(1), 1-14.

Börjesson, S., \& Löfsten, H. (2012). Capabilities for innovation in small firms-A study of 131 high-tech firms and their relation to performance. International Journal of Business Innovation and Research, 6(2), 149-176.

Brinckmann, J., Salomo, S., \& Gemuenden, H. G. (2011). Financial management competence of founding teams and growth of new technology-based firms. Entrepreneurship Theory and Practice, 35(2), $217-243$.

Brown, R., \& Mason, C. (2014). Inside the high-tech black box: A critique of technology entrepreneurship policy. Technovation, 34(12), 773-784.

Butchart, R. L. (1987). A new UK definition of the high technology industries. Economic Trends, 400, $82-88$.

Chandler, G. N., \& Hanks, S. H. (1994). Market attractiveness, resource-based capabilities, venture strategies and venture performance. Journal of Business Venturing, 9(4), 331-349.

Clarysse, B., Bruneel, J., \& Wright, M. (2011). Explaining growth paths of young technology-based firms: Structuring resource portfolios in different competitive environments. Strategic Entrepreneurship Journal, 5(2), 137-157.

Cohen W. M., Nelson, P. R., \& Walsh J. P. (2000). Protecting their intellectual assets: Appropriability conditions and why U.S. manufacturing firms patent (or not). NBER working paper Cambridge, Massachusetts.

Colombo, M. G., \& Grilli, L. (2005). Founders' human capital and the growth of new technology-based firms: A competence-based view. Research Policy, 34(6), 795-816.

Conti, A., Thursby, J., \& Thursby, M. (2013). Patents as signals for startup financing. The Journal of Industrial Economics, 61(3), 592-622.

D’Ambrosio, A., Gabriele, R., Schiavone, F., \& Villasalero, M. (2017). The role of openness in explaining innovation performance in a regional context. The Journal of Technology Transfer, 42(2), 389-408.

Das, T. K., \& Teng, B. S. (1997). Time and entrepreneurial risk behaviour. Entrepreneurship Theory and Practice, 22(2), 69-88.

Davidsson, P. (2007). Strategies for dealing with heterogeneity in entrepreneurship research. In Paper presented August 7th at the Academy of Management Conference, Philadelphia.

Davidsson, P., \& Honig, B. (2003). The role of social and human capital among nascent entrepreneurs. Journal of Business Venturing, 18(3), 301-331.

Davis, L., \& Kjaer, K. (2003). Patent strategies of small Danish high-tech firms. In Paper presented June 12-14 at the DRUID summer conference, Copenhagen/Elsinore.

Deeds, D., Decarolis, D. L., \& Coombs, J. E. (2000). The determinants of research productivity in high technology ventures: An empirical analysis of new biotechnology firms. Journal of Business Venturing, 15(2), 211-229.

DeVellis, R. F. (1991). Scale development: Theory and applications (applied social research methods series) (Vol. 26). Newbury Park: Sage.

DeVon, H. A., Block, M. E., Moyle-Wright, P., Ernst, D. M., Hayden, S. J., Lazzara, D. J., et al. (2007). A psychometric toolbox for testing validity and reliability. Journal of Nursing Scholarship, 39(2), $155-164$

Elfring, T., \& Hulsink, W. (2003). Networks in entrepreneurship: The case of high-technology firms. Small Business Economics, 21(4), 409-422.

Elfring, T., \& Hulsink, W. (2007). Networking by entrepreneurs: Patterns of tie-Formation in emerging organizations. Organization Studies, 28(12), 1849-1872.

Ferguson, R., \& Olofsson, C. (2004). Science parks and the development of NTBFs-location, survival and growth. The Journal of Technology Transfer, 29(1), 5-17.

Fontana, R., Nuvolari, A., Shimizu, H., \& Vezzulli, A. (2013). Reassessing patent propensity: Evidence from a dataset of R\&D awards, 1977-2004. Research Policy, 42(10), 1780-1792.

Freel, M. S. (2003). Sectoral patterns of small firm innovation, networking and proximity. Research Policy, 32(5), 751-770.

George, D., \& Mallery, P. (2003). SPSS for Windows step by step: a simple guide and reference. 11.0 update (4th ed.). Boston, MA: Allyn \& Bacon.

Giones, F., \& Brem, A. (2017). Digital technology entrepreneurship: A definition and research agenda. Technology Innovation Management Review, 7(5), 44-51.

Grindley, P. C., \& Teece, D. J. (1997). Managing intellectual capital: Licensing and cross-licensing in semiconductors and electronics. California Management Review, 39(2), 8-41.

Gulati, R. (1998). Alliances and networks. Strategic Management Journal, 19(4), 397-420. 
Gulati, R. (1999). Network location and learning: The influence of network resources and firm capabilities on alliance formation. Strategic Management Journal, 20(5), 397-420.

Haeussler, C., Harhoff, D., \& Mueller, E. (2014). How patenting informs VC investors-The case of biotechnology. Research Policy, 43(8), 1286-1298.

Hair, J. F., Anderson, R. E., Tatham, R. L., \& Black, W. C. (1995). Multivariate data analysis (3rd ed.). New York: Macmillan Publishing Company.

Hite, J. M., \& Hesterly, W. S. (2001). The evolution of firm networks: From emergence to early growth of the firm. Strategic Management Journal, 22(3), 275-286.

Hitt, M. A., Dacin, M. T., Levitas, E., Arregle, J. L., \& Borza, A. (2000). Partner selection in emerging and developed market contexts: Resource-based and organizational learning perspectives. Academy of Management Journal, 43(3), 449-467.

Hoang, H., \& Antoncic, B. (2003). Network-based research in entrepreneurship: A critical review. Journal of Business Venturing, 18(2), 165-187.

Hottenrott, H., Hall, B. H., \& Czarnitzki, D. (2016). Patents as quality signals? The implications for financing constraints on R\&D. Economics of Innovation and New Technology, 25(3), 197-217.

Kelley, D. J., \& Mark, P. R. (2002). Leveraging the value of proprietary technologies. Journal of Small Business Management, 40(1), 1-16.

Klevorick, A. K., Levin, R. C., Nelson, R. R., \& Winter, S. G. (1995). On the sources and significance of interindustry differences in technological opportunities. Research Policy, 24(2), 185-205.

Klofsten, M., Jonsson, M., \& Simón, J. (1998). Supporting the pre-commercialization stages of technologybased firms: The effects of small-scale venture capital. Venture Capital, 1(1), 83-93.

Kollmer, H., \& Dowling, M. (2004). Licensing as a commercialisation strategy for new technology-based firms. Research Policy, 33(8), 1141-1151.

Krammer, S. M. S. (2009). Drivers of national innovation in transition: Evidence from a panel of Eastern European countries. Research Policy, 38(5), 845-860.

Lefebvre, L. A., \& Lefebvre, E. (1993). Competitive positioning and innovative efforts in SMEs. Small Business Economics, 5(4), 297-306.

Letaifa, S. B., \& Rabeau, Y. (2013). Too close to collaborate? How geographic proximity could impede entrepreneurship and innovation. Journal of Business Research, 66(10), 2071-2078.

Levin, T. C., Klevorick, A. K., Nelson, R. R., \& Winter, S. G. (1987). Appropriatingthe returns from industrial research and development. Brookings Papers on Economic Activity, 18(3), 783-820.

Lindelöf, P., \& Löfsten, H. (2004). Proximity as a resource base for competitive advantage: Universityindustry links for technology transfer. The Journal of Technology Transfer, 29(3-4), 311-326.

Löfsten, H. (2014). Information structures and business performance-Implications for technology-based firm's innovation performance. Knowledge and Process Management, 21(4), 246-259.

Löfsten, H. (2015). Critical resource dimensions for development of patents-An analysis of 131 new technology-based firms in incubators. International Journal of Innovation Management, 19(1), 1550006.

Löfsten, H. (2016a). Business and innovation resources: Determinants for the survival of new technologybased firms. Management Decision, 54(1), 88-106.

Löfsten, H. (2016b). New technology-based firms and their survival-The importance of business networks, and entrepreneurial business behaviour and competition. Local Economy, 31(3), 393-409.

Löfsten, H., \& Lindelöf, P. (2002). Science parks and the growth of new technology-based firms-Academic-industry links, innovation and markets. Research Policy, 31(6), 859-876.

Löfsten, H., \& Lindelöf, P. (2003). Determinants for an entrepreneurial milieu-Science parks and business policy in growing firms. Technovation, 23(1), 51-64.

MacCallum, R. C. (1990). The need for alternative measures of fit in covariance structure modeling. Multivariate Behavioral Research, 25(2), 157-162.

Maine, E. M., Shapiro, D. M., \& Vining, A. R. (2010). The role of clustering in the growth of new technology-based firms. Small Business Economics, 34(2), 127-146.

Markusen, A., Hall, P., \& Glasmeier, A. (1986). High tech America: The what, how, where and why of the sunrise industries. Boston, MA: George Allen and Unwin.

Marquis, C., \& Tilcsik, A. (2013). Imprinting: Toward a multilevel theory. Academy of Management Annals, $7(1), 195-245$.

Mason, K., \& Chakrabarti, R. (2016). The role of proximity in business model design: Making business models work for those at the bottom of the pyramid. Industrial Marketing Management, 61, 67-80.

McDougall, P., Phillips, P., Covin, J. G., Robinson, R. B. J., \& Herron, L. (1994). The effects of industry growth and strategic breath on new venture performance and strategy content. Strategic Management Journal, 15(7), 537-554.

Monck, C. S. P., Porter, R. B., Quintas, P., Storey, D. J., \& Wynarczyk, P. (1988). Science parks and the growth of high technology firms. London: Croom Helm. 
Morris, M., Schindehutte, M., \& Allen, J. (2005). The entrepreneur's business model: Toward a unified perspective. Journal of Business Research, 58(6), 726-735.

Nambisan, S. (2017). Digital entrepreneurship: Toward a digital technology perspective of entrepreneurship. Entrepreneurship Theory and Practice, 41(6), 1029-1055.

Niosi, J. (2006a). Introduction to the symposium: Universities as a source of commercial technology. The Journal of Technology Transfer, 31(4), 399-402.

Niosi, J. (2006b). Success factors in Canadian academic spin-offs. The Journal of Technology Transfer, 31(4), 451-457.

Nunnally, J., \& Bernstein, I. (1994). Psychometric theory. New York: McGraw-Hill.

Phillips, D. (1991). New alliances for policy and the conduct of research and education. International Journal of Technology Management, 6(5/6), 478-487.

Presutti, M., Boari, C., \& Majocchi, A. (2013). Inter-organizational geographical proximity and local startups' knowledge acquisition: A contingency approach. Entrepreneurship and Regional Development, 25(5-6), 446-467.

Ramírez-Alesón, M., \& Fernández-Olmos, M. (2017). Unravelling the effects of science parks on the innovation performance of NTBFs. The Journal of Technology Transfer. https://doi.org/10.1007/s1096 $1-017-9559-\mathrm{y}$.

Ravix, J. L. (2014). Localization, innovation and entrepreneurship: An appraisal of the analytical impact of Marshall's notion of industrial atmosphere. Journal of Innovation Economics and Management, 2(14), 63-81.

Rivette, K. G., \& Kline, D. (2000). Discovering new value in intellectual property. Harvard Business Review, 78(1), 54-66.

Saemundsson, R. J., \& Candi, M. (2014). Antecedents of innovation strategies in new technology-based firms: Interactions between the environment and founder team composition. Journal of Product Innovation Management, 31(5), 939-955.

Safón, V. (2009). Measuring the reputation of top us business schools: A mimic modeling approach. Corporate Reputation Review, 12(3), 204-228.

Santoro, M. D., \& Gopalakrishnan, S. (2001). Relationship dynamics between university research centers and industrial firms: Their impact on technology transfer activities. The Journal of Technology Transfer, 26(1-2), 163-171.

Simsek, Z., Fox, B. C., \& Heavey, C. (2015). "What's past is prologue" A framework, review, and future directions for organizational research on imprinting. Journal of Management, 41(1), 288-317.

Soto-Acosta, P., Popa, S., \& Palacios-Marqués, D. (2017). Social web knowledge sharing and innovation performance in knowledge-intensive manufacturing SMEs. The Journal of Technology Transfer, 42(2), $425-440$.

Statistics Sweden. (2007). http://www.scb.se/en_/Documentation/Classifications-and-standards/SwedishStandard-Industrial-Classification-SNI/.

Stuart, T. B., Hoang, H., \& Hybels, R. C. (1999). Interorganizational endorsements and the performance of entrepreneurial ventures. Administrative Science Quarterly, 44(2), 315-349.

Taylor, C., \& Silberston, A. (1973). The economic impact of the patent system. Cambridge: Cambridge University Press.

Uzzi, B. (1996). The source and consequences of embededdness for the economic performance of organizations: The network effect. American Sociological Review, 61(4), 674-698.

Uzzi, B. (1997). Social structure and competition in inter firm networks: The paradox of emededdness. Administrative Science Quarterly, 42(1), 35-67.

Vásquez-Urriago, A. R., Barge-Gil, A., \& Rico, A. M. (2016). Science and technology parks and cooperation for innovation: Empirical evidence from Spain. Research Policy, 45(1), 137-147.

Walker, G., Kogut, B., \& Shan, W. J. (1997). Social capital, structural holes and the formation of an industry network. Organization Science, 8(2), 109-125.

Wennberg, K. (2005). Entrepreneurship research through longitudinal databases: measurement and design issues. New England Journal of Entrepreneurship, 8(2), 9-19.

Yli-Renko, H., Autio, E., \& Sapienza, H. J. (2001). Social capital, knowledge acquisition, and knowledge exploitation in young technology-based firms. Strategic Management Journal, 22(6-7), 587-613.

Yu, G. J., \& Lee, J. (2017). When should a firm collaborate with research organizations for innovation performance? The moderating role of innovation orientation, size, and age. The Journal of Technology Transfer, 42(6), 1451-1465. 